\title{
Longitudinal dimensions of land-use impacts in riverine ecosystems
}

Dimensóes longitudinais do impacto do uso do solo em ecossistemas de rios

Rafael Feijó-Lima ${ }^{1}$ (D), Eugenia Zandonà ${ }^{2 *}$ (D), Bruna Suelen da Silva ${ }^{1}$ (D), Flavia Tromboni ${ }^{13}$ (D), Timothy Peter Moulton ${ }^{2}$ (D) and Steven Arnold Thomas ${ }^{4}$

'Programa de Pós-graduação em Ecologia e Evolução, Universidade do Estado do Rio de Janeiro UERJ, Rua São Francisco Xavier, 524, Maracaná, CEP 20550-013, Rio de Janeiro, RJ, Brasil

${ }^{2}$ Programa de Pós-graduação em Ecologia e Evolução, Departamento de Ecologia, Universidade do Estado do Rio de Janeiro - UERJ, Rua São Francisco Xavier, 524, Maracanã, CEP 20550-013, Rio de Janeiro, RJ, Brasil

${ }^{3}$ Global Water Center and Biology Department, University of Nevada, 1664 N, Virginia Street, Reno 89557, NV, United States of America

${ }^{4}$ School of Natural Resources, University of Nebraska-Lincoln, 101 Hardin Hall, 3310 Holdrege Street, Lincoln, NE 68583-0961, United States of America

*e-mail: eugenia.zandona@gmail.com

Cite as: Feijó-Lima, R. et al. Longitudinal dimensions of land-use impacts in riverine ecosystems. Acta Limnologica Brasiliensia, 2019, vol. 31, e107.

Abstract: Aim: Rivers are linked longitudinally via the flow of water and the spatial dimensions of the changes in local riparian vegetation are still poorly understood. Recent modifications to the Native Vegetation Protection Law allow reduction of lateral buffer strips and amnesty for riparian vegetation removal, which might increase the fragmentation of native riparian vegetation, especially for Atlantic Rainforest streams. Methods: We present two case studies conducted in a stream draining a fragmented landscape in the Atlantic Rainforest. The stream flows through two abrupt transitions (forest-pasture-forest) and we investigated how far the upstream effects of a given riparian condition could be detected in the downstream reach for a suite of variables. Results: We show that the effects of land cover propagate downstream for both algal and macroinvertebrate communities. For some variables of interest, these effects might extend up to a $\mathrm{km}$ downstream from the transition. Conclusions: There is a need to understand how the distribution of riparian forest remnants contribute to maintaining watershed-scale resilience to impacts.

Keywords: Atlantic Rainforest streams; habitat fragmentation; watersheds; land cover; longitudinal effect.

Resumo: Objetivo: Os rios são conectados longitudinalmente através do fluxo de água e as dimensôes espaciais dos efeitos das mudanças na vegetação ripária local ainda são pouco compreendidas. Mudanças recentes na Lei de Proteção da Vegetaçáo Nativa permitem a redução de faixas laterais de proteção e anistia para a remoçáo de vegetação ciliar, o que pode aumentar a fragmentação da vegetação nativa, especialmente para riachos da Mata Atlântica. Métodos: Apresentamos dois estudos de caso realizados em um riacho que drena uma paisagem fragmentada na Mata Atlântica. O riacho flui através de duas transiçôes abruptas (floresta-pasto-floresta) e investigamos até que ponto os efeitos a montante de uma determinada condiçấo ribeirinha poderiam ser detectados a jusante para um conjunto de variáveis. Resultados: Os efeitos da cobertura da terra se propagaram a jusante tanto nas comunidades de algas como nas de macroinvertebrados e, para algumas variáveis de interesse, esses 
efeitos podem se estender até um $\mathrm{km}$ a jusante da transição. Conclusóes: Há uma necessidade de entender como a distribuição dos remanescentes florestais ciliares contribui para manter a resiliência aos impactos na escala de bacias.

Palavras-chave: rios de Mata Atlântica; fragmentação de habitat; bacias hidrográficas; cobertura do solo; efeito longitudinal.

\section{Introduction}

The Atlantic Rainforest in Brazil is highly impacted by habitat fragmentation due to human activities such as pasture for animal rearing, agriculture, and urbanization (SOS Mata Atlântica \& INPE, 2018). Over $60 \%$ of the Brazilian population is concentrated in the Atlantic Rainforest domain (Scarano \& Ceotto, 2015), with most of the population in the Southern, South-Eastern and North-Eastern states of Brazil relying on Atlantic Rainforest watersheds for drinking water, agricultural production, and energy generation. These are, not coincidentally, the areas where human uses of water are the most vulnerable to water supply stress due to poor management practices (Vörösmarty et al., 2010; Gassert et al., 2013), supply shortages caused by precipitation anomalies (Otto et al., 2015; Getirana, 2016) and environmental disasters (Fernandes et al., 2016; Gonçalves, 2019).

The Native Vegetation Protection Law (LPVN), popularly known as the New Brazilian Forest Code (Novo Código Florestal), represents the most recent overhaul of forestry and land use management laws. This new piece of legislation, introduced in 2012, provides for a reduction in the ranges of riparian vegetation buffers to be preserved under the title of Permanent Preservation Areas (APPs, Portuguese acronym). In the New Forest Code, the established width of an APP now varies not only considering the width of the river in question, but also the size of the rural properties. In small rural properties (4 to 10 Fiscal Modules, area unit that varies for each municipality), deforestation can reach $90 \%$ around rivers between 100 and 600 meters wide. Moreover, riparian buffer width for certain combinations of property size, river or stream width and recovery requirements can be as low as $5 \mathrm{~m}$ wide (SOS Mata Atlântica, 2016). This new piece of legislation also provides an amnesty to land owners that had forests removed as of 22 July 2008.

This amnesty for riparian vegetation removal for small land-owners might have more nefarious effects for riverine systems than anticipated. Small streams (first to third order) constitute over $80 \%$ of the river length in the world (Downing et al., 2012), and this percentage is likely to be higher for humid small basins with high drainage density, such as those present in tropical rainforests (Allen \& Pavelsky, 2018). And it is also within these basins that the integrity of riparian vegetation exerts the strongest controls in the physical, chemical and biological characteristics of the adjacent stream.

The effects of land-cover changes on different biological components of streams and rivers and the consequences of these to the structure and function of small streams is well documented (Fausch et al., 2002; Malmqvist \& Rundle, 2002; Allan, 2004). Riparian vegetation also influences channel geomorphology, sediment loading and hydrological conditions (Gregory et al., 1991). In addition, leaf fall from adjacent vegetation represents an important energy source for macroinvertebrates and fish communities and can strongly influence stream ecosystem structure and function (Newbold et al., 1982; Simon \& Collison, 2002; Sweeney \& Bott, 2004; Poff et al., 2006). These riparian effects are particularly important in headwater streams that are heavily shaded by riparian vegetation and where the importance of allochthonous (e.g. leaves) food sources is expected to be greatest (Vannote et al., 1980; Richardson \& Danehy, 2007).

Due to historical reasons, the NE, SE and $S$ regions of Brazil (which contain most of the Atlantic rainforest domain) are the areas with the highest concentration of small and medium sized land properties (Brazilian Institute of Geography and Statistics IBGE, 2018). These small rural properties are often located in the headwaters of these watersheds due to higher land values associated with lowland areas (Silva et al., 1983). Therefore, even under a scenario where the new riparian vegetation dimensions were to be progressively established to the full extent required by law, the patchiness of native vegetation surrounding headwater streams will still be pervasive. To our knowledge, there are no studies that have quantified the actual river length that is going to undergo riparian forest loss due to these new rules (but see Rezende et al., 2018 for estimates of actual riparian vegetation cover and perspectives in degradation and recovery due to new legal requirements).

Despite public outcry over changes in the law, there are few spatially explicit studies which 
focus on the determination of the actual sizes of riparian buffers that are necessary to achieve specific conservation goals. In fact, most of the discussion about the size of APPs and legal reserves in available literature focuses on terrestrial environments (Rodrigues et al., 2009; Metzger, 2010; Soares-filho et al., 2014) and the scientific basis for establishing the dimensions of riparian vegetation forest that are necessary to maintain riverine ecosystems is sparse, with the arguments for the preservation of specific dimensions of riparian forests being usually based on a precautionary principle.

Rivers are linear, spatially continuous, heterogeneous habitat patches that are intimately linked to their catchment landscapes through water flow (Fausch et al., 2002; Allan, 2004). Despite the large investments that usually accompany riparian vegetation restoration projects, the spatial aspects of riverine ecosystem recovery efforts are still poorly understood (Palmer et al., 2007). Remediation actions for watershed scale impacts are rarely implemented in the whole watershed, with priority actions being selected based on tradeoffs among environmental, economic, political, and social factors. Restoration actions are often spatially constrained by the available candidate sections, as well as by the amount of river length that such projects encompass.

From a watershed management perspective, it is important to determine how heterogeneous conditions of riparian vegetation interact longitudinally and how these impacts are propagated along the watershed (Harding et al., 2006; Feijó-lima et al., 2018). This longitudinal perspective of upstream impacts is typical of running waters and has rarely been employed (but see Suga $\&$ Tanaka, 2013; Goss et al., 2014; Tanaka et al., 2015; Feijó-lima et al., 2018). The extension of these transition zones and the length of these longitudinal effects may vary substantially depending on the hydrology and geomorphology (e.g. discharge, sediment, etc.) of the stream, as well as on the response variable considered (e.g. temperature, algae and invertebrate biomass, primary and secondary productivity). Many of these variables might show a spatial lag in their response to riparian transitions, which we have termed as the "penetrance effect".

The pattern and magnitude of change of a given variable in response to riparian transition has rarely been investigated and even less so the distance necessary for it to achieve a new stable condition (Figure 1). Abiotic variables and biological communities can respond differently to these abrupt changes, generally showing a spatial lag in response to riparian conditions (Scarsbrook \& Halliday, 1999; Niyogi et al., 2007; Suga \& Tanaka, 2013; Goss et al., 2014; Feijó-lima et al., 2018). Some variables can respond more quickly to the riparian transitions (e.g. temperature, algae), while others require longer distances to fully transition into a new stable state (e.g. invertebrate community metrics, decomposition and nutrient cycling). Different models and scenarios can describe how an abiotic or biotic variable "penetrates" into the downstream condition until reaching a new downstream steady state (Figure $1 \mathrm{~B}$ and $\mathrm{C}$ ).

Here, we present two case studies conducted in a stream draining a fragmented landscape in the Atlantic Rainforest. The stream presents two abrupt transitions (forest-pasture-forest) and our objective was to investigate the spatial dimensions of the response of a suite of variables to abrupt riparian vegetation transitions. We applied the penetrance framework for a suite of variables of interest along these abrupt riparian boundaries, in order to quantify either the downstream buffering or restoration effect provided by the presence of these forest remnants.

\section{Case Studies of Transition Zones in a Tropical Stream}

We studied a second-order stream, Itaperiti, a tributary of the Guapiaçu River, in Rio de Janeiro State, Brazil. The Itaperiti stream is located in the Atlantic Rainforest and originates from a preserved forest (Três Picos State Park) and flows into a mosaic of vegetation, including pasture, agriculture, and forest remnants. We conducted a high-resolution spatial sampling into two continuous transition zones - forest-to-pasture and pasture-to-forest remnant - collecting physical, chemical, and biological samples to quantitatively estimate longitudinal spatial patterns.

\subsection{Case study 1}

We studied the upstream abrupt transition of the Itaperiti stream, from a forested undisturbed section to a downstream pasture section. The sampling was conducted at every $75 \mathrm{~m}$ for $1050 \mathrm{~m}$. We quantified a suite of physical, chemical and biological variables, as well as benthic invertebrate community metrics. In summary, selected variables that presented monotonic behavior along the land cover transitions were regressed against distance using nonlinear models. These models were produced based on the 

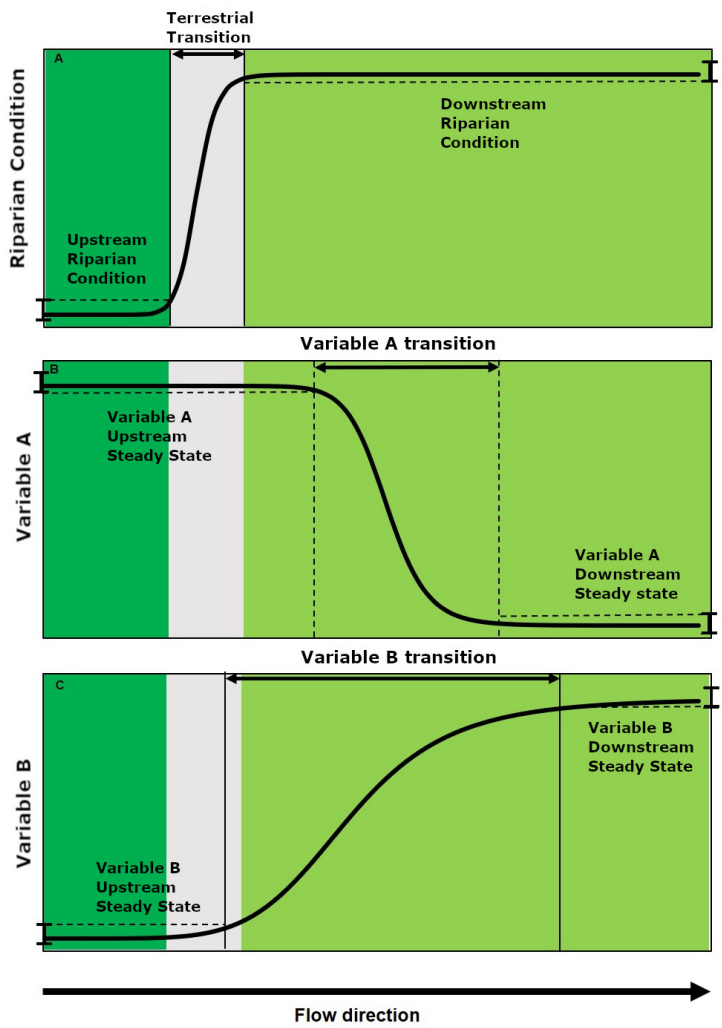

Figure 1. Expected behavior of two potential variables (panel B and C) in response to the change in riparian condition (panel A). The dark green area indicates the stable riparian condition upstream, the grey area indicates the terrestrial transition in riparian vegetation from the upstream to the downstream condition, and the light green area indicates the stable downstream riparian condition. Panel B and C show the potential responses of two different variables to the changes in the terrestrial riparian condition, transitioning from the upstream steady state to the downstream steady state. The variable in panel B shows a much faster response to the changes in riparian conditions, reaching the downstream steady state at a shorter distance compared to the variable shown in panel C. The variable in panel $\mathrm{B}$ also shows a delayed response compared to the variable in panel C.

assumption that a stable condition for a given variable could be detected either upstream, downstream or both, along the sampled transition (Figure 1). Model selection was performed using the Bayesian Information Criterion (BIC) (Raftery, 1995).

Along that abrupt transition, we were able to quantify downstream lags in key biological variables, such as chlorophyll $a$ concentration and invertebrate functional feeding group proportions, to which both variables responded with a downstream lag to the changes in canopy cover (Figure 2). It is especially interesting to observe the cascading effect of riparian change through the different biological compartments: a decrease in canopy cover is followed by an increase in benthic chlorophyll $a$ concentration. The algae-associated invertebrates (collector-gatherers) followed the chlorophyll $a$ response, but with a delay (Figure 2). The main results of this study can be found in Feijó-Lima et al. (2018).

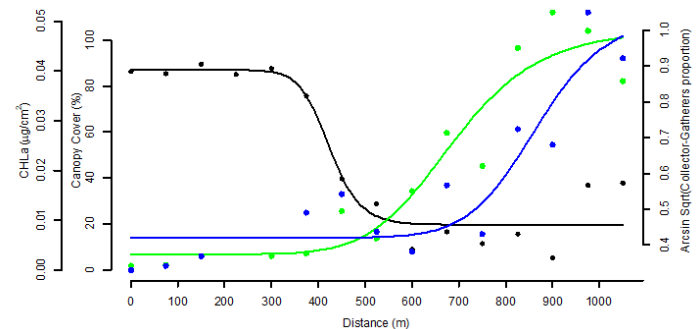

Figure 2. Selected nonlinear models for canopy cover percentage (black), benthic chlorophyll $a$ concentration (green), and collector-gatherer invertebrate proportion throughout the 15 sampling sites along the forest-pasture transition in the Itaperiti stream (Rio de Janeiro, Brazil). Note different scales for the different variables.

\subsection{Case study 2}

Case study 2 was also performed in the Itaperiti stream, but we sampled an additional transition. We used both the forest-to-pasture transition cited 
in the previous study, as well as a second pasture to forest transition located downstream from the pasture section. By having a forest-pasture-forest transition design, we could test the potential of the downstream forest section to mitigate the effects of the upstream pasture reach. We could thus test if and the distance needed to some biological variables to return to the steady state of the upstream undisturbed forest section.

We performed an algal accrual experiment, using ceramic tiles placed in the stream for 14 days in each sampling point. We measured algal stock both by chlorophyll $a$ and ash-free dry mass measurements. We also quantified algal taxonomic composition through microscopic analysis and algal pigments via fluorescence using a PHYTO-PAM phytoplankton analyzer (Heinz Walz GmbH, Effeltrich, Germany) (Lürling et al., 2018). Nonlinear model fitting and selection was performed using the same methods described for case study 1 .

Our results showed that the proportion of algal brown pigments mirrored the change in riparian cover, showing a similar sigmoidal pattern in both transitions as canopy cover change, but with a spatial lag in response relative to changes in riparian cover (Figure 3). These results suggest that the downstream forest remnant buffers the effect of the upstream pasture, as algal condition returns to its pre-impact state - i.e. similar levels as in the non-impacted upstream forest. Other variables measured responded in a different shape to the riparian transitions. For instance, cyanobacteria had

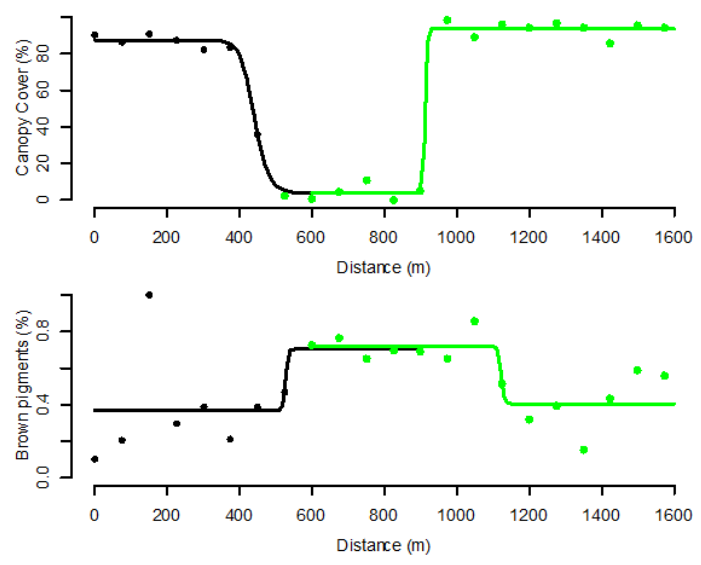

Figure 3. Selected models for canopy cover percentage (top panel) and brown pigments percentage in algae samples (bottom panel) throughout the 22 sampling sites along the forest-pasture-forest transitions in the Itaperiti stream (Rio de Janeiro, Brazil). Lines represent nonlinear fits for the upstream (Black) and downstream (Green) transitions. not been recorded in the upstream forest reach, but they appeared in the pasture section, although in lower abundance, in the downstream forest remnant. Along the second transition, the downstream forest fragment did not reset, but only partially mitigated the effect of the upstream pasture, decreasing but not eliminating cyanobacteria presence.

\section{Future Directions, Information Gaps: What is Urgent to Do?}

Restoring and maintaining forests and forest remnants can have positive effects in promoting stream health and ecosystem services. Upstream riparian patches can buffer downstream ecological conditions when transitioning into reaches without riparian cover. Conversely, forest fragments located downstream of impacted reaches (e.g. pasture, agriculture) could mitigate the negative effects of the lack of riparian cover and restore stream functioning, in a so-called "forest reset effect" (Harding et al., 2006). However, impacts of land use at the catchment scale may outweigh the benefits of local stream riparian buffers (Wahl et al., 2013) and little is known about what the extension of the remnants should be in order to maintain or restore stream ecological integrity.

Being able to quantify the downstream mitigation potential of riparian forest remnants is of utmost importance in order to guarantee that management, conservation and restoration efforts are effective in maintaining stream ecosystems health and integrity as well as their ability in providing ecosystem services. In order to do so, we need a comprehensive theoretical framework for longitudinally monitoring and assessment of the success of riverine restoration efforts. Ultimately, understanding the connectivity between restored areas is critical to understanding how restoration actions interact longitudinally and how the spatial dimensions and distribution of restoration efforts contribute to maintaining watershed resilience.

More studies should therefore focus on assessing not only local but longitudinal mitigation effects of riparian reforestation efforts. We believe that the modeling approach outlined in this report represents a first step towards an objective approach for quantifying the longitudinal dimensions of riparian land use impacts on streams. This approach will likely benefit from cross-system comparisons to account for variation in discharge, velocity, and other environmental variables, as well as comparisons with other theoretical frameworks (e.g., nutrient spiraling). 
With the penetrance framework we provide a starting point that can be used to evaluate the patchiness of previous restoration efforts as a natural experiment. From our two case studies we showed that effects seem to not always be symmetrical as to distance, magnitude or penetration between adjacent stream segments. In addition, as flow characteristics change, it is likely that so will the distance downstream that an impact will be propagated.

There is a current need to carry out studies that evaluate the impacts of riparian forest loss on aquatic ecosystems in a spatially explicit way (sensu Feld, 2013). Such studies could identify the longitudinal dimensions of change that accompany the loss or restoration of riparian vegetation and provide insights on strategic management practices that can help maintaining the integrity of headwater streams in the face of current and future deforestation pressures. We strongly believe that it is important to study the joint effects of lateral land-cover changes and downstream flow and material transport to understand how changes in riparian conditions are manifested downstream and assess the effectiveness of a minimum riparian forest size protection able to maintain healthy streams.

\section{Acknowledgements}

We thank the Ecological Reserve of Guapiaçú (REGUA) for their logistical support and Dr. M.M. Marinho for lending us the PHYTO-PAM. The research was supported by CAPES program Science Without Borders - project n. 166/2012 to TPM, and by FAPERJ (E-26/112.066/2013-INST) and CNPq Universal (477503/2013-6) to EZ. The authors were supported by the following scholarships: RF-L - CAPES PhD scholarship; TPM - Prociência UERJ; EZ - FAPERJ JCNE, Prociência UERJ; BSdS - FAPERJ IC; FT - CAPES/FAPERJ PAPD E-26/100.018/2015 and Macrosystems 1442562.

\section{References}

ALLAN, J.D. Landscapes and riverscapes: the influence of land use on stream ecosystems. Annual Review of Ecology Evolution and Systematics, 2004, 35(1), 257-284. http://dx.doi.org/10.1146/annurev. ecolsys.35.120202.110122.

ALLEN, G.H. and PAVELSKY, T.M. Global extent of rivers and streams. Science, 2018, 361(6402), 585588. http://dx.doi.org/10.1126/science.aat0636. PMid:29954985.
DOWNING, J.A., COLE, J.J., DUARTE, C.M., MIDDELBURG, J.J., MELACK, J.M., PRAIRIE, Y.T., KORTELAINEN, P., STRIEGL, R.G., MCDOWELL, W.H. and TRANVIK, L.J. Global abundance and size distribution of streams and rivers. Inland Waters, 2012, 2(4), 229-236. http://dx.doi. org/10.5268/IW-2.4.502.

FAUSCH, K.D., TORGERSEN, C.E., BAXTER, C.V. and LI, H.W. Landscapes to riverscapes: bridging the gap between research and conservation of stream fishes. Bioscience, 2002, 52(6), 483. http://dx.doi. org/10.1641/0006-3568(2002)052[0483:LTRBT G]2.0.CO;2.

FEIJÓ-LIMA, R., MCLEAY, S.M., SILVA-JUNIOR, E.F., TROMBONI, F., MOULTON, T.P., ZANDONÀ, E., and THOMAS, S.A. Quantitatively describing the downstream effects of an abrupt land cover transition : buffering effects of a forest remnant on a stream impacted by cattle grazing. Inland Waters, 2018, 1(3), 1-18. http://dx.doi.org/10.1080/20442 041.2018.1457855.

FELD, C.C.K. Response of three lotic assemblages to riparian and catchment-scale land use: Implications for designing catchment monitoring programmes. Freshwater Biology, 2013, 58(4), 715-729. http:// dx.doi.org/10.1111/fwb.12077.

FERNANDES, G.W., GOULART, F.F., RANIERI, B.D., COELHO, M.S., DALES, K., BOESCHE, N., BUSTAMANTE, M., CARVALHO, F.A., CARVALHO, D.C., DIRZO, R., FERNANDES, S., GALETTI JUNIOR, P.M., MILLAN, V.E.G., MIELKE, C., RAMIREZ, J.L., NEVES, A., ROGASS, C., RIBEIRO, S.P., SCARIOT, A. and SOARES-FILHO, B. Deep into the mud: ecological and socio-economic impacts of the dam breach in Mariana, Brazil. Natureza \& Conservação, 2016, 14(2), 35-45. http://dx.doi.org/10.1016/j. ncon.2016.10.003.

GASSERT, F., LANDIS, M., LUCK, M., REIG, P. and SHIAO T. Aqueduct global maps 2.1. Washington: World Resources Institute, 2013. 31 p.

GETIRANA, A. Extreme water deficit in Brazil detected from space. Journal of Hydrometeorology, 2016, 17(2), 591-598. http://dx.doi.org/10.1175/ JHM-D-15-0096.1.

GONÇALVES, L.R.M., trans. Three years after Mariana, a new dam bursts in Brazil, causing at least 34 deaths [online]. Folha de São Paulo, 2019 [viewed 16 Jul. 2014]. Available from: https://www1.folha.uol.com. br/internacional/en/brazil/2019/01/three-years-aftermariana-a-new-dam-bursts-in-brazil-causing-atleast-11-deaths.shtml

GOSS, C.W., GOEBEL, P.C. and SULLIVAN, S.M.P. Shifts in attributes along agriculture-forest transitions of two streams in central Ohio, USA. Agriculture, Ecosystems \& Environment, 2014, 197, 106-117. http://dx.doi.org/10.1016/j.agee.2014.07.026. 
GREGORY, S.V., SWANSON, F.J., MCKEE, W.A. and CUMMINS, K.W. An ecosystem perspective of riparian zones. Bioscience, 1991, 41(8), 540-551. http://dx.doi.org/10.2307/1311607.

HARDING, J.S., CLAASSEN, K. and EVERS, N. Can forest fragments reset physical and water quality conditions in agricultural catchments and act as refugia for forest stream invertebrates? Hydrobiologia, 2006, 568(1), 391-402. http://dx.doi.org/10.1007/ s10750-006-0206-0.

INSTITUTO BRASILEIRO DE GEOGRAFIA E ESTATÍ́STICA - IBGE. Censo Agro 2017. Rio de Janeiro: IBGE, 2018.

LÜRLING, M., MELLO, M.M., VANOOSTERHOUT, F., DOMIS, L.S., and MARINHO, M.M. Response of natural cyanobacteria and algae assemblages to a nutrient pulse and elevated temperature. Frontiers in Microbiology, 2018, 9, 1851. http://dx.doi. org/10.3389/fmicb.2018.01851.

MALMQVIST, B. and RUNDLE, S. Threats to the running water ecosystems of the world. Environmental Conservation, 2002, 29(2), 134-153. http://dx.doi. org/10.1017/S0376892902000097.

METZGER, J.P. O código florestal tem base científica? Natureza \& Conservação, 2010, 8(01), 92-99. http:// dx.doi.org/10.4322/natcon.00801017.

NEWBOLD, J.D., MULHOLLAND, P.J., ELWOOD, J.W. and O'NEILL, R.V. Organic carbon spiralling in stream ecosystems. Oikos, 1982, 3(3), 266-272. http://dx.doi.org/10.2307/3544663.

NIYOGI, D.K., KOREN, M., ARBUCKLE, C.J. and TOWNSEND, C.R. Longitudinal changes in biota along four New Zealand streams: Declines and improvements in stream health related to land use. New Zealand Journal of Marine and Freshwater Research, 2007, 41(1), 63-75. http:// dx.doi.org/10.1080/00288330709509896.

OTTO, F.E.L., HAUSTEIN, K., UHE, P., COELHO, C.A.S., ARAVEQUIA, J.A., ALMEIDA, W., KING, A., PEREZ, E.C., WADA, Y., JAN VAN OLDENBORGH, G., HAARSMA, R., VAN AALST, M. and CULLEN, H. Factors other than climate change, main drivers of 2014/15 water shortage in southeast Brazil. Bulletin of the American Meteorological Society, 2015, 96(12), S35-S40. http:// dx.doi.org/10.1175/BAMS-D-15-00120.1.

PALMER, M., ALLAN, J.D., MEYER, J. and BERNHARDT, E.S. River Restoration in the Twenty-First Century: Data and Experiential Knowledge to Inform Future Efforts. Restoration Ecology, 2007, 15(3), 472-481. http://dx.doi. org/10.1111/j.1526-100X.2007.00243.x.

POFF, N.L., BLEDSOE, B.P. and CUHACIYAN, C.O. Hydrologic variation with land use across the contiguous United States: Geomorphic and ecological consequences for stream ecosystems.
Geomorphology, 2006, 79(3-4), 264-285. http:// dx.doi.org/10.1016/j.geomorph.2006.06.032.

RAFTERY, A.E. Bayesian Model Selection in Social Research. Sociological Methodology, 1995, 25, 111163. http://dx.doi.org/10.2307/271063.

REZENDE, C.L., SCARANO, F.R., ASSAD, E.D., JOLY, C.A., METZGER, J.P., STRASSBURG, B.B.N., TABARELLI, M., FONSECA, G.A. and MITTERMEIER, R.A. From hotspot to hopespot : An opportunity for the Brazilian Atlantic. Perspect Ecol Conserv., 2018, 16(4), 208-214. http://dx.doi. org/10.1016/j.pecon.2018.10.002.

RICHARDSON, J.S. and DANEHY, R.J. A synthesis of the ecology of headwater streams and their riparian zones in temperate forests. Forest Science, 2007, 53, 131-147.

RODRIGUES, R.R., LIMA, R.A.F., GANDOLFI, S. and NAVE, A.G. On the restoration of high diversity forests : 30 years of experience in the Brazilian Atlantic Forest. Biological Conservation, 2009, 142(6), 1242-1251. http://dx.doi.org/10.1016/j. biocon.2008.12.008.

SCARANO, F.R. and CEOTTO, P. Brazilian Atlantic forest: impact, vulnerability, and adaptation to climate change. Biodiversity and Conservation, 2015, 24(9), 2319-2331. http://dx.doi.org/10.1007/ s10531-015-0972-y.

SCARSBROOK, M.M.R. and HALLIDAY, J. Transition from pasture to native forest land-use along stream continua: Effects on stream ecosystems and implications for restoration. New Zealand Journal of Marine and Freshwater Research, 1999, 33(2), 293-310. http://dx.doi.org/10.1080/00288330.19 99.9516878.

SILVA, J.G., KAGEYAMA, A.A., ROMÃO, D.A., WAGNER NETO, J.A.W. and PINTO, L.C.G. Tecnologia e campesinato: o caso brasileiro. Brazilian J Polit Econ [online]. 1983 [viewed 16 Jul. 2014], 3(4), 94. Available from: https://ideas.repec.org/a/ ekm/wpaper/v3y1983i4a94.html

SIMON, A. and COLLISON, A.J.C. Quantifying the mechanical and hydrologic effects of riparian vegetation on streambank stability. Earth Surface Processes and Landforms, 2002, 27(5), 527-546. http://dx.doi.org/10.1002/esp.325.

SOARES-FILHO, B., RAJÃO, R., MACEDO, M., CARNEIRO, A., COSTA, W., COE, M., RODRIGUES, H., ALENCAR, A. Cracking Brazil's forest code. Science, 2014, 344(6182), 363-364. http://dx.doi.org/10.1126/science.1246663.

SOS MATA ATLÂNTICA. O novo código florestal nos estados da Mata Atlântica [online]. Sáo Paulo: Fundação SOS Mata Atlântica, 2016 [viewed 03 Abr. 2019]. Available from: https://www.sosma.org. br/wp-content/uploads/2016/05/SOSMA-Estudo_ CODIGO-CAR_Final_ONLINE.pdf 
SOS MATA ATLÂNTICA and INSTITUTO NACIONAL DE PESQUISAS ESPACIAIS - INPE. Atlas dos remanescentes florestais da mata atlântica periodo 2016-2017. São José dos Campos: INPE, 2018. $63 \mathrm{p}$.

SUGA, C.M. and TANAKA, M.O. Influence of a forest remnant on macroinvertebrate communities in a degraded tropical stream. Hydrobiologia, 2013, 703(1), 203-213. http://dx.doi.org/10.1007/s10750012-1360-1.

SWEENEY, B. and BOTT, T. Riparian deforestation, stream narrowing, and loss of stream ecosystem services. Proceedings of The National Academy of Sciences of United States of America, 2004, 101(39), 1413214137. http://dx.doi.org/10.1073pnas.0405895101

TANAKA, M.O., FERNANDES, J.D.F., SUGA, C.M., HANAI, F.Y. and SOUZA, A.L.T. Abrupt change of a stream ecosystem function along a sugarcaneforest transition: Integrating riparian and in-stream characteristics. Agriculture, Ecosystems \& Environment,
2015, 207, 171-177. http://dx.doi.org/10.1016/j. agee.2015.04.014.

VANNOTE, R.R.L., MINSHALL, G.W., CUMMINS, K.W., SEDELL, J.R. and CUSHING, C.E. The river continuum concept. Can J, 1980, 37, 130-137.

VÖRÖSMARTY, C.J., MCINTYRE, P.B., GESSNER, M.O., DUdGEON, D., PRUSEVICH, A., GREEN, P., GLIDDEN, S., BUNN, S.E., SULLIVAN, C.A., LIERMANN, C.R. and DAVIES, P.M. Global threats to human water security and river biodiversity. Nature, 2010, 467(7315), 555-561. http://dx.doi.org/10.1038/ nature09440. PMid:20882010.

WAHL, C.M., NEILS, A. and HOOPER, D. Impacts of land use at the catchment scale constrain the habitat benefits of stream riparian buffers. Freshwater Biology, 2013, 58(11), 2310-2324. http://dx.doi. org/10.1111/fwb.12211.

Received: 03 April 2019 Accepted: 27 June 2019 